UDK: 821.111.09-821 Eliot, T. S.

821.111.09-821 Anderson, S.

Original scientific paper

Received on September 2, 2019

Denis Kuzmanović

University of Mostar, Faculty of Humanities and Social Sciences

denis.kuzmanovic@ff.sum.ba

\title{
INABILITY OF SELF-EXPRESSION IN THE SELECTED WORKS OF ELIOT AND ANDERSON
}

\section{Abstract}

At first glance, T. S. Eliot and Sherwood Anderson do not seem to have much in common when their works are considered. Eliot is known primarily for his poetry and Anderson for his short stories. The former is often considered an English author and the latter an American one. The first is one of the most recognizable names of Modernism, and the second is often considered a realist. Eliot is known for the complexity and inaccessibility of his poetry and Anderson's works appear much simpler in comparison. Eliot is famous for his urban imagery and Anderson for his rural setting. However, there is one theme they have in common: the exploration of an individual's inability of self-expression in his surroundings, where the expression is affected by materialistic, artistic, sexual or other issues with accompanying repressions. This desire for self-expression or self-realization contrasts with the mores of one's society and their failed attempts to express themselves bring along depression, frustration, repression and alienation, something that both Eliot and Anderson knew well, because they also struggled with some of the issues of their protagonists. An important notion here is that the exploration of this inability seems to suggest its universality or ubiquity, regardless if the individual is living in a big city or a small rural community. Upon closer analysis of these themes, the differences start to fade and other connections appear, such as Eliot's use of the caricature or grotesque to heighten certain states of mind, something that Anderson also does; 
indeed, the first story in his work Winesburg, Ohio is called Book of the Grotesque, but with a more sympathetic and less ironic flavour. Evening and night are very important times for both authors, as that is when an individual's introspection, mostly unconscious, is intensified. Social critique is very prominent and the compatibility of public and private lives is also explored.

Keywords: T.S. Eliot; Sherwood Anderson; self-expression; Modernism; realism; repression; society; grotesque

Many people mistake Eliot for an English poet, since he spent most of his adult life in England and was granted English citizenship in 1927, but he was born in St. Louis and the importance of his American background and upbringing on his creative output was significant. In the 1959 interview Eliot acknowledged the value of his life in England regarding his works, but also stated that it is "a combination of things. But in its sources, in its emotional springs, it comes from America" ("The Parisian Review," 1959). Eliot's poetry frequently features alienated and repressed individuals pitted against society, and individualism has always been one of the crucial parts of the American way of life, perhaps more so than in any other culture. This probably originated, at least in part, from the early Puritan settlers who had to carve their own identity and position in the new world. Indeed, Eliot's Puritan heritage with its emphasis on sin, guilt, fallibility and self-doubt remained strong throughout his life. His parents, however, raised him as a Unitarian, a somewhat liberal branch of Christian Presbyterianism, where the importance was on rational intellectualism and pragmatism. The emphasis on practicality instead of strict morality did not appeal to Eliot, as Scofield notes: "He also once spoke of how his parents did not talk of good and evil, but of what was 'done' and 'not done"' $(1988,11)$. His propensity for intensity, passion and introspection, along with the aforementioned guilt, sin and suffering almost seems like the old Puritanism of his ancestors was archetypal in Eliot, despite his upbringing, and these themes were frequently explored in his poetry. Besides religion, another important influence on Eliot was the urban setting of St. Louis, and descriptions 
of urban squalor which are so pervasive in his poetry trace their origin from this big industrial city. The aptly used word squalor did not, however, exclusively refer to the decay of this city, as Eliot would subsequently incorporate metropolises like Paris and London in his urban images. He described the neighbourhood where he lived as "shabby to a degree approaching slumminess" (Bush, 1991, 49). In fact, the memorable yellow smoke and fog in Prufrock came from the factory chimneys of St. Louis.

An individual's alienation in an industrial modern city is intensely but, true to modernism, also implicitly explored in Eliot's Preludes, written in 1910-1911 when his experience of living in America was still fresh. The poem showcases some of Eliot's modernist techniques and it is divided into four parts of unequal length with intermittent rhyme. The routine of repetitive jobs is presented as detrimental because this kind of existence deadens the people who cannot realize their potential and achieve happiness. The beginning of the twentieth century was marked by rapid advancements in technology and factory production on a vast scale. The best example was Ford's conveyor belt, where an individual virtually became merely one piece in machinery because of the monotonous nature of the work. The pollution of smoke and trash adds to the dreary atmosphere. The first part of Preludes paints an evening picture of this with images like the "burnt-out ends of smoky days" (Eliot, 1963, 13), or "the grimy scraps / Of withered leaves about your feat" (Eliot, 1963, 13), where the pronoun your effectively emphasizes the atmosphere by immersing the reader in it, as if we could actually experience it. The setting is certainly that of squalor, as the speaker describes "broken blinds and chimney pots" (Eliot, 1963, 13) and a solitary stamping cab horse in the light of the lamps. The second part opens with a morning which does not bring energy from a good night sleep. Instead it is filled with a "faint stale smells of beer" (Eliot, 1963, 13), and the people trudge like zombies to refreshment before going to work: "With all its muddy feet that press / To early coffee stands" (Eliot, 1963, 13). Eliot uses synecdoche to convey the sense of alienation since only parts of people are described, as if they cannot feel or be, or even appear their full selves: 
"One thinks of all the hands / That are raising dingy shades / In a thousand furnished rooms" (Eliot, 1963, 13).

There is a repetition of the word you in the beginning of the third part, where readers are supposed to imagine themselves lying and dozing in bed, observing "the night revealing / The thousand sordid images/ Of which your soul was constituted" (Eliot, 1963, 14). It is at night when the unconscious mind reveals all the repressed daytime thoughts and feelings, because they are then reined in by authority, routine and work. In the following line the arrival of the morning seems to dispel whatever insight gained earlier, indicated by the word had, and the word street could symbolize life or existence itself: "You had such a vision of the street / As the street hardly understands" (Eliot, 1963, 14). The image of an individual / reader sitting on a bed's edge and clasping his soiled feet with soiled hands is that of both desperation and frustration. The fourth part moves briefly into third person narration and continues with the bleakness, as the routine and schedule of clock and papers appears to be the only consolation for the people: "And evening newspaper, and eyes / Assured of certain certainties" (Eliot, 1963, 14). This carries with it the numbness and relief from whatever sort of vagueness the conscious mind abhors. Here in the word eyes synecdoche is again used, as if wittily implying that they, not the mind itself, are the only prerequisite for reading, because nothing in the newspaper is of any substance. Near the end the speaker assumes the first person view again as if to provide a commentary on the entire situation. Unsurprisingly, the descending evening provides an impetus for introspection, where his interest is in the "fancies that are curled / Around those images" (Eliot, 1963, 14) and that the entire existence in all of this is ironically described as "some infinitely gentle / Infinitely suffering thing" (Eliot, 1963, 15). The poem closes with the speaker's ironic advice that we should simply give in and laugh at all of this because it is so absurd and entropic, as is the image in this objective correlative: "The worlds revolve like ancient women / Gathering fuel in vacant lots" (Eliot, 1963, 15).

The short poem "Morning at the Window" depicts the lives of people during the day, where everybody wakes up into a languid state of 
cheerlessness: "I am aware of the damp souls of housemaids / Sprouting despondently at area gates" (Eliot, 1963, 19). The word sprouting colourfully conveys the ubiquity of this mood in many people who pop up in the morning like mushrooms. The motif of fog is once again evoked in the final stanza: "The brown waves of fog toss up to me / Twisted faces from the bottom of the street" (Eliot, 1963, 19), where the warped faces of people not only describe the state of alienation and frustration but also pointlessness. The subsequent surreal image of an aimless smile hovering and fading in the air shows that life appears to be in some kind of fog as well, as it is insubstantial and lacks foundation. This etherealness is what people could be experiencing because they lack a foundation to grab a hold of their lives. They lack a more meaningful life and are merely floating.

Prose poem "Hysteria" published in 1915 depicts this eponymous emotional state in a woman who is sexually repressed. The first person speaker accompanying her feels not only uncomfortable but also afraid that this state will somehow transfer to him as well: "As she laughed I was aware of becoming involved in her laughter and being part of it" (Eliot, 1963, 24). The speaker tries to appear reserved, a very important attitude in polite society, but the lingering fear betrays him in the expressions he uses to describe his female companion; her "teeth were only accidental stars" (Eliot, 1963, 24), so this supposedly localized state threatens to become vast, even cosmic. The fear is that this will somehow infect other people and their repressions will spring to the surface. Despite his intentions, he becomes absorbed in her laughter in the beginning of the poem, intermitted with "short gasps" (Eliot, 1963, 24) of air and in the "dark caverns of her throat" (Eliot, 1963, 24). The indication that this may very well be sexual repression comes from the phrase "ripple of / unseen muscles" (Eliot, 1963, 24). This unnerves the waiter as well, another representative of a wider or conventional society, and his reaction is telling in that the speaker twice repeats the line: "If the lady and gentleman wish to take their / tea in the garden" (Eliot, $1963,24)$, which reflects the polite, but uncomfortable attitude of the society to the awkward, taboo issues, especially that of female sexuality. 
The reader cannot help but to be reminded of the rigid moral norms of Victorian society, were such hormonally and emotionally charged states in women were actually described as hysteria. When something like this occurs, there is a morally conditioned reflex among people to try and restore the respectful appearance at all costs, instead of straightforward dealing with the situation, and the erotic image of "shaking of her breasts" (Eliot, 1963, 24) highlights once again the speaker's embarrassment when confronted with this so directly. Indeed, there is a strong desire to return to the formality of a socially appropriate but apparently not very meaningful chat, to restore "the fragments of the afternoon" (Eliot, 1963, 24). Of course, there should not be any honesty and directness in approaching this issue, but a very careful "subtlety to this end" (Eliot, 1963, 24). This poem serves as a good commentary of the way an individual's repression, in this case sexual, burgeons its way from sub consciousness to the morally chained consciousness, hence the bizarre behaviour of the woman, but also people in general.

The Love Song of Alfred J. Prufrock is one of the best known examples of modernist poetry, not only in its structure but in exploration of an individual's fragmented mind. This poem may be the quintessential representative of the theme of this essay, as Prufrock's failure of self-expression is threefold: sexual, intellectual (or creative), and material (or social). This is a very complex poem with numerous multi-layered themes, tones and plentiful references to other authors' works. There are also elements of satire and absurdity, not to mention the mocking of conventional poetic conventions, from structure to content. The analysis here will be limited to the individual, i.e. Prufrock and the observations concerning his expression. Considering all the great changes which the twentieth century brought, it is no wonder that the mind struggled to keep up with them, both inwardly and outwardly. The use of the first person speaker / protagonist emphasizes the deep insight into his personality, or personalities. It is widely believed that Prufrock is thinly disguised Eliot, and the modernist techniques can serve to mask the autobiographical elements of one's life, to provide distance between himself and his work in order to make the themes more emblematic of the entire 
society. The poem was written between 1910 and 1911 in a period where Eliot was traveling between the US and Europe and beginning to settle in England. One can safely assume that it was a trying time for him, attempting to establish his identity in all those new circumstances. These experiences are the source of Prufrock's anguish and in order to make poetry truly relevant and valuable, a poet must write what he knows, as Eliot said: "All significant truths are private truths" (Scofield, 1988, 17).

If we take the view that Prufrock is essentially communicating with himself, then it can be argued that he is trying to reconcile the conscious and unconscious parts of his psyche. The latter is trying to bring forth all the repressed issues stemming from the unrealized self, and the former is mostly blocking it due to fear of societal ostracizing. Freud's terminology of the psyche can be introduced here if we oversimplify all of this to a certain extent. Id, or pleasure principle, in a rough comparison would try to fulfil the unrealized repressed desires and emotions; super-ego, or the morality principle, would block them because of id's incompatibility with the conventional society; and the ego, or the reason principle, would be the mediator between these two. The complex interplay of these three parts is presented in the poem, and once again, night time is the proper catalyst. The unconscious mind encourages Prufrock in the beginning of the poem to go on a journey, and the evening setting is established with Eliot's famous trademark, the objective correlative, i.e. an abstract concept compared to a concrete image: "When the evening is spread out against the sky / Like a patient etherized upon a table" (Eliot, 1963, 3). The purpose of this technique seems to be the grounding of these subconscious abstractions so that the conscious mind can grasp them better. The languid night is a suitable canvas of sorts, upon which Prufrock's impressions can be painted. The nocturnal alienating atmosphere is emphasized by phrases like "half-deserted streets" (Eliot, 1963, 3), or "muttering retreats" (Eliot, 1963, 3). The mysterious purpose of it all may yield unpleasant results, the realization of a wasted life, perhaps, where the alleys of this internal exploration will be like "streets that follow like a tedious argument / Of insidious intent" (Eliot, 1963,3 ) and the journey itself seems to be more important than answers, 
whatever they may be: "Oh, do not ask, 'What is it?' / Let us go and make our visit" (Eliot, 1963, 3).

The frustration over lack of self-expression starts to manifest itself more clearly, and the motif of the pretentiousness of the higher social class, or even middle class, where they try to present themselves as intellectuals, but only for appearances, is established by these lines: "In the room the women come and go / Talking of Michelangelo" (Eliot, 1963 , 3). This environment of pretence does not appeal to our protagonist as his creativity cannot flourish there. Eliot's recognizable motif of fog is featured as well, namely the yellow fog of his home town which licks its tongue, falls back and leaps. This personification conveys the absurd, or surreal atmosphere as the fog obfuscates things and impressions alike. Indeed, it is as if the sinister fog serves to cloud the attempts of insight from Prufrock's psyche, because as the fog is "rubbing its back upon the window panes" (Eliot, 1963, 4), the socially conditioned urge of the super ego tries to take over: "There will be time, there will be time / To prepare a face to meet the faces that you meet" (Eliot, 1963, 4). The reader should note the indefinite article before the word face, which implies that one must have many faces in order to be accepted. The lines: “'Do I dare?' and, 'Do I dare?"' (Eliot, 1963, 4) could signify his trepidation of approaching a love interest, or making his intentions known to her, and after this pondering he gives up: "Time to turn back and descend the stair" (Eliot, 1963, 4). He knows that strict social protocols and decorum are preventing him to pursue this interest freely, and this imposed reserve is reflected in the way he, but also many people in general, dress: "My morning coat, my collar mounting firmly to the chin" (Eliot, 1963, 4). Here the morning coat may also be significant because the need for pretence is required more during the day in a social and business environment. Prufrock is aware that he is stuck in a vicious circle of daylight existing and nocturnal questioning. The situation and the questions he asks himself are all too familiar: "For I have known them all already, known them all; / Have known the evenings, mornings, afternoons" (Eliot, 1963, 4). The numbing effects of routine and schedule are very sapping: "I have measured out my life with coffee spoons" (Eliot, 
1963, 4). Just like in Preludes, synecdoche is used where the people he meets appear to him only as parts of personalities whose speeches and behaviour he can predict with certainty: "And I have known the eyes already, known them all- / The eyes that fix you in a formulated phrase" (Eliot, 1963, 5). Social criticism continues with a synecdoche of women's arms in fine bracelets, but this sight jolts him again to sexual frustration: "Is it perfume from a dress /That makes me so digress" (Eliot, 1963, 5) and to the familiar reluctance to approach them: "And should I then presume? / How should I begin?" (Eliot, 1963, 5).

An individual's estrangement becomes universal in the lines: "Of lonely men in shirt sleeves, leaning out of windows" (Eliot, 1963, 5). Prufrock does not fall into the romantic trap of mythologizing or aggrandizing his suffering and is able to check the temptation: "I have seen the moments of my greatness flicker, / And I have seen the eternal Footman hold my coat, and snicker" (Eliot, 1963, 6). His fervent mind has the propensity of contemplating all sorts of vague great questions amidst a myriad of banal descriptions of things like porcelain, pillow, sunsets, teacups, novels and skirts. It is a parody of the pretence of great intellectuals and philosophers exercised by people from certain social classes, it being desirable in order to succeed, and Prufrock is not exempt from all this. By mocking this pretence, he acknowledges that he has it, and it does not appear that he is successful; this could be interpreted as his frustration arising from inability of achieving material and social advancement. He at least temporarily, or nocturnally, as it were, rejects this false philosophy which is expressed in the motif "This is not what I meant at all" (Eliot, 1963, 6). The real need for expression could lie in honest and direct communication with people, but once again the norms stand in the way. The insight is not to last and Prufrock knows that he will not make any substantial change in this regard, and to that effect he compares himself to two well-known literary figures; he is not noble Hamlet with real issues: "No! I am not prince Hamlet, nor was I meant to be" (Eliot, 1963, 6) but more of a Polonius who can only "swell a progress, start a scene of two" (Eliot, 1963, 6). Despite this unflattering self-description, there is a lingering impression throughout this internal 
monologue that Prufrock is not an ordinary individual, that he indeed has the capacity to be something more, but does not have the faith in himself. This self-mocking is his coping mechanism to deal with repression and frustration. The closing lines depict his fantasies regarding mermaids' song, white waves and the sea wind; near the end the speaker uses the we point of view which could mean that all parts of his psyche are united in this escapist, even sexual, fantasy but it only lasts "Till human voices wake us, and we drown" (Eliot, 1963, 7). The voices are those of the morning, working people; the daylight is here now and we drown into normalcy, routine and rules. All three aforementioned frustrations are once again buried and the cycle presumably continues.

Sherwood Anderson is primarily known for his highly esteemed short story collection Winesburg, Ohio, published in 1919. On its publication most reviews had actually been unflattering, to say the least; something similar occurred with the initial critical reaction of Eliot's early poetry as well. As it is often the case in conservative societies, the backlash came because of the perceived offensive sexual themes, as Anderson said in one of his letters: "It was called immoral and ugly. Even the word 'filthy' was frequently used" (Modlin and White, 1996, 143). Over time critical acclaim followed because the primary value of Winesburg is that it portrays the inability of self-expression in a small American community. This defied the widely held notion that everybody in such a place would be known by everybody else and could not possibly feel alienated. Anderson shows that the estrangement and frustration of the modern man is practically ubiquitous regardless of the size of the community. Winesburg features stores, saloons, small businesses, natural landscape, farms, untouched fields, and all of this is a far cry from the foggy industrial dirtiness of Eliot's urban imagery, but the underlying issues of the characters, or as Anderson calls them, grotesques, are practically the same. Anderson speaks of the universality of influences on an individual, and they are primarily that of the wider society, institutions, family and peers. His work helped to subsequently make famous the image of a seedy underbelly of a small American town. It is significant that Anderson's inspiration came from the Chicago slums, like those of St. Louis, 
where he was living for a while and experienced difficulties in artistic expression, and principally from the people he frequently encountered. He wrote: "and the truth is that I got the substance for every character in the book not from an Ohio village, but from other people living around me in the Chicago tenement" (Modlin and White, 1996, 145). Winesburg, Ohio, like Eliot's poems, is not only modernist in content but also in form. Anderson sports a deceptively simple style, uses the techniques of understatement and omission, later popularized and developed by Hemingway's iceberg theory, and sometimes apparently meaningless digressions. The most important modernist contribution is that the stories themselves are unconventionally structured, especially the ending which is devoid of the contemporarily popular didactic closure. The purpose of endings like these is to reflect life itself, where it often happens that the big issues are not resolved, and the grotesques have to live with them, are stuck with them and doomed to stagnate. Anderson was opposed to the clever plotting and structures of the contemporary short story authors, where their works were specifically designed to provide a punch at the end where everything would be resolved. His stories often leave the readers with the sense of unease, and they are not, as he said, "nice little packages, wrapped and labeled in the O'Henry manner" (Modlin and White, 1996, 149). This had a far reaching influence on subsequent modernists like Hemingway, Faulkner and Fitzgerald.

Few characters in Winesburg develop or come to some stage of self-realization or expression. Most of them experience a change for the worse at one point in their lives, both mentally, being traumatized, suffering injustices, tragedies, experiencing thwarted dreams and desires, and physically or materially, being sick, poor, shabby and dirty. Thwarted dreams and desires is the most important theme for analysing Winseburg, as many had high hopes of becoming something better until life wore them down. Repression is a common motif in the stories and it is mainly, just like in Eliot's poetry, creative, sexual and / or material.

The story "Mother" deals with the familial relationship between Tom Willard, his wife Elizabeth and their son George. Tom is the proprietor of a failing hotel and there is much crudeness in his manners and 
personality. Consequently, his self-expression and frustration are of the simplest kind: material. There are no modernist techniques in his portrayal; everything is immediately understandable to the reader, which reflects the shallowness of the character. Tom had big plans for the hotel business, but they never succeeded. He keeps up with the appearance of a confident entrepreneur but is secretly dismayed by Elizabeth's presence who serves as a reminder of his failures. Curiously enough, he was, as the narrator sarcastically observes, "a leading Democrat in a strongly Republican community" (Anderson, 1919, 16) which depicts his ineptitude and stubbornness. Tom's vain hopes of Winesburg soon becoming a Democrat stronghold whereby his influence and business plans would improve dramatically, describe how his thinking has little basis in reality. Even the dreams of becoming a congressman or a governor are not too foolish for him. He also likes to magnify and exaggerate his political influence, as the example of his confrontation with a fellow Democrat in a political conference shows: "Look at what I've done here! I was a Democrat here in Winseburg when it was a crime to be a Democrat. In the old days they fairly hunted us with guns" (Anderson, 1919, 16). Despite of pretensions and arrogance, but only when he is not around his wife, Tom deep down knows that he is a failure, so he invests all of his failed ambitions into his son and with his last remaining influence manages to arrange a newspaper job for him. He thinks that teaching his son to strive for wealth is the best lesson he can give. Making money is the American way, and this again likely stems from the Puritan, Protestant heritage where it was religiously pleasing and good to be successful in business. He frequently tells George to wake up and quit being too deep into thoughts, he should strive for business success right now. The possibility of his son not making it is too horrible to contemplate, so with perhaps desperate confidence he says to him: "You're not a fool and you're not a woman. You're Tom Willard's son and you'll wake up. I'm not afraid" (Anderson, 1919, 19). Tom's failed self-realization clearly makes him a frustrated materialist.

Elizabeth Willard is a more complex case, and so is her portrayal. Anderson's modernist technique is immediately present in the beginning 
of the story, where the thin, bloodless, spectre-like, prematurely older woman is described as if suffering from "some obscure disease [that] had taken the life out her figure" (Anderson, 1919, 16). It is later revealed that this disease is actually a dissatisfaction with her life. She wanders through the almost empty hotel like a ghost, constantly being reminded of the bad cards life had dealt her. There was really no love between her and her husband, so she transferred it all to her only child George upon whom she invested all of her dreams and hopes, as parents often do. Thus her "half forgotten," or repressed yearning is projected onto him, and she dreams that he will become a great person she never was. When she looks at him from a distance, her zeal increases, feeling like it is her life's mission not to allow George to become nothing less than what he was meant to be. She's willing to suffer through anything so that her boy may "be allowed to express something for us both" (Anderson $1919,17)$. When in his company, she is reserved, almost shy, as feeling in awe of him. At this point, the reader cannot know for sure what is that she wants her son to be, but it is certainly something more than just a successful business man. There is a digression in the story of the conflict between a baker and druggist's cat, and after watching this familiar and mundane scene, she bursts into tears. Nothing is explicitly stated, but this meaningless event seems to reflect her own dreary and empty life. The narrator over the course of the story allows us to glimpse into her life in more details, as when she overhears the conversation of her husband and son and feels furious after. It becomes obvious that she rejects Tom's materialistic influence. The fury dispels the weakness and energizes her for the long awaited confrontation with her husband. There is a quite melodramatic scene with her grabbing the scissors with the intent to hurt him. Then the narrator provides us with Elizabeth's background, when her father owned the hotel and she was already known in the community as being free spirited and doing things unbecoming a young girl, such as wearing men's clothes, riding a bicycle, socializing with acting troupes, etc. She felt confined by her environment, wanted to see the world and experience life to the full. It is once again only implied that she may have engaged in sexual relations with men: "It was 
always the same, beginning with kisses and ending after strange wild emotions, with peace and then sobbing repentance" (Anderson 1919, 17). In this simple sentence Anderson is able to express the themes of life's restlessness, sexual awakening, romance, sexual satisfaction and guilt because of the super-ego, or the societal moral norms prohibiting such behaviour. The story then returns to the present and Elizabeth is described looking at her theatrical makeup box. Now the reader knows that she wanted to be an actress, an artist, she wanted creative expression, but it did not happen. Her flare for melodrama, when we note the scissors, also makes sense now. She begins to apply makeup and construct the conflict in her mind as if staging a theatrical scene. She wants to appear to Tom as beautiful and frightening at the same time, a heroine worthy of some elevated tragedy. Repressed desires burst forth only in her imagination, however, as she soon gives up the idea, symbolically blowing out the candle in front of her. George unexpectedly visits her and cockily proclaims that he wants to leave the town for some unknown purpose. He immediately dispels her fears declaring that he is not interested in material success, saying instead that "I don't know what I shall do. I just want to go away and look at people and think" (Anderson 1919, 17). She is overjoyed, but has lost the capacity to express it; mother and son awkwardly chat about something else to break the silence, but the unspoken understanding between them is strongly implied as the story ends.

Anderson continues Elizabeth's story much later in Winesburg, in the story called "Death", which is about her special relationship with Dr. Reefy. Their conversation goes beyond medical problems as Elizabeth is basically undergoing some sort of psychological therapy, as people do when they honestly talk about deeper issues. It feels like the two are kindred spirits, both of them have the need to express that which is buried: "something inside them meant the same thing, wanted the same release" (Anderson, 1919, 123). These meetings have been happening for several years, and each time both of them are more relaxed and share more things. She feels rejuvenated after these meetings, like she was experiencing a second youth; needless to say, this stops once she is in 
her dreary home. The narrator again brings us back to Elizabeth's past and we learn that her mother died when she was still a child and that her father was unhappy with his professional life of a hotel owner, and that he could not really communicate with his daughter. She was basically left on her own and had multiple lovers when she was eighteen, but none of them fulfilled her desire of an idealized true romance. She was searching for something greater in her relationships, something that could fulfil her not only sexually, but creatively and emotionally: "In all the babble that fell from the lips of the men with whom she adventured she was trying to find what would be for her the true word" (Anderson 1919, 125). She married Tom out of convenience, i.e. because she was taught by the society that at a certain point, it was proper for a woman to marry. She was seeing other girls marrying and she felt that a deeper significance of the marriage would also beneficially affect her if she was to be like them. Her father was unhappy with this and urged her to take his hidden cash and go to some other town. Here we can also see the failed desires of parents transferring to their children; her father was unable to make something more of his life, not in the material sense, even though he failed at this as well, so she wished that his daughter could succeed where he did not. Elizabeth did not use this opportunity, as she still hoped that marriage, or the notion of marriage would make her happy. She had high expectations, not only because of her personality, with her being prone to romanticizing and idealization, but also because she felt that if she did the proper things that were expected of her, the society would owe her happiness: "It wasn't Tom I wanted, it was marriage" (Anderson, 1919, 126).

Soon in her marriage she began to feel like in prison and when Tom told her of his plans to make the hotel business better, the thought of living an ordinary life awakened her repressed creative side and she went for a ride and fell into a near hysterical state, wanting to tear her clothes, a symbol of her conventional, or "moral" shell. Unfortunately, her self-expression was too vague, she knew she wanted something else, but did not have a clear idea of what it was, as she confides to Dr. Reefy twenty years later: "I wanted to run away from everything but I wanted 
to run towards something too" (Anderson, 1919, 126). The doctor shares similar sentiments and is overcome by passion, because something in her story affects him deeply. He starts to kiss her passionately, calling her "dear." This is an important symbol because previously in the story the narrator described how her other lovers from her youth also called her dear. But he is a different man, and she finally seems to have found her true lover, somebody who understands her and her desires. However, a mundane incident in his office interrupts the burgeoning relationship. As they are embracing, with Elizabeth also giving in to her feelings, the steps of a store clerk delivering something frightens her very much. The thought of being judged by the society of infidelity, i.e. her super-ego overpowers her. Elizabeth's diagnosis is the constant battle between the id and the super-ego and one could say this was common for many women living in a patriarchal conservative society, where a desire for happiness is continuously clashing with the values of the society prohibiting it, because it limited the woman's role to being a wife and a mother. This state of severe disharmony finally exhausts her completely and she never gets to be her true self. She spends her last few months yearning for release, for death. Ironically enough, Death, the bringer of long awaited peace, appears to become her true lover and she waits for him until the end.

Themes of sexual awakening, desire for happiness and Winesburg's confines are explored in the character of Alice Hindman in the story "Adventure". The narrator uses the back and forth plot to present her life, and how it regressed from optimistic and hopeful when she was a teenager to repressed and bleak in her late twenties. When sixteen, she had a passionate relationship with a young man, Ned Currie, who wanted to move to a bigger city and have a journalist career. Alice also desired to escape her unfulfilling life in this small community and planned to go with him; she wisely suggested that in a big city nobody would mind if they were together but not married yet. Ned was somewhat perplexed by her determination and maturity, but told her she should stay here; he would come back for her once he earned some money. Just before he left, they became lovers and that was the event that marked 
her life. Although none of them were ashamed of it, Alice's somewhat modified super-ego made her believe that now they were forever bound and that her fate was inextricably bound to his. As it usually happens, Ned went to the big city of Chicago and intoxicated by the energetic life there eventually forgot about Alice.

She is, however, now trapped in Winesburg, working as a store clerk and waiting for something that will not come. She immerses herself in the routine job, believing that the waiting will be more tolerable. She refuses the advances of other men, believing that she belongs solely to Ned, since, for her, sexual relationship is as binding as marriage. She refers to herself as his wife and the narrator cannot help but ironically comment: "and for all her willingness to support herself could not have understood the growing modern idea of a woman's owning herself and giving and taking for her own ends in life" (Anderson, 1919, 61). Here we can see a strange modern dichotomy in Alice; she is a mature and capable girl, making her own money and supporting herself, but is still enslaved by the motion that sex means marriage, and that she is compelled to obey that bond, although the second party is absent. Perhaps this is why her super-ego is different in that it does not condemn pre-marital sex, but equates it with marriage. Life's circumstances made her briefly taste happiness but now her life is severely lacking, with her days spent at the store where she continuously "arranged and rearranged the stock" (Anderson, 1919, 61). At night she yearns for her lover, and eventually, even for the mere idea of a lover. Alice longs for love and to be loved, physically and emotionally, and her sexual repressions are intensifying. It is poignant how she later folds the blanket in her bed to resemble a human form, so she will not be alone at night.

The natural landscape of Winseburg and the fertile fields are an archetype of fertility and sexual energy which unconsciously affects Alice in this way, like archetypes do. The most devastating moment is when Alice seems resigned to her fate, realizing that Ned, or her happiness will never come. She cries, yields to this thought and has a somewhat cathartic moment: "she cried, and an odd sense of relief came with this" (Anderson, 1919, 63). Such is the power of habitual daily existence, 
routine and endurance; she is getting used to her misery. Even though she tries to be in the company of another person from town, she has been alone for so long that the yearning for an actual man fades and only vague abstractions are now present; she can hardly remember Ned anymore. Despite this apparent tough exterior, her repression breaks forth one rainy night in a daring manner when she goes outside naked. The rejuvenating and benevolent effect of rain makes her enter to the core of her being, the pure id, pure sexual desire, with the manacles of society briefly broken: "She thought that the rain would have some creative and wonderful effect on her body" (Anderson, 1919, 63). The word body from the previous quote is telling; Alice for a long time neglected her physical needs (the id) and had only concentrated on the super-ego, unnecessarily being chaste and denying herself happiness because she felt that was what a woman was supposed to do.

This is another case of sacrificing personal happiness for the sake of societal values concerning women. Naked in the rain, the desire for love and satisfaction is so intense that she even calls somebody in the distance, unable to tolerate her loneliness any longer. Ironically, the man is partly deaf and does not see or hear who is calling, symbolizing the whole society which does not acknowledge Alice's needs and desires. Then Alice's super-ego prevails and she hurries to her room, gets dressed and cries bitterly. The all too familiar suffering and habits sentence her to continued unhappiness, the previously awakened repressed urge not having enough power to set her free, and she "began trying to force herself to face bravely the fact that many people must live and die alone, even in Winesburg" (Anderson, 1919, 64). As mentioned, Anderson shows that the perceived paradox of being alone and lost in the small community is just as real as alienation in large cities in Eliot's poems.

The comparison of Eliot and Anderson in this regard highlights the brave depiction of people's unrealized selves and the detrimental consequences of accompanying repression. Naturally, this plight is not new and exclusive for the twentieth century but it was more pronounced then due to all the new things and ideas which all sorts of changes brought. Authors like Eliot and Anderson with a gift of acute insight into 
people's mind broke new ground in their time in defying the previously held concepts on what constituted one's happiness and how it could be pursued and realized. Through both form and content, they ruffled quite a few feathers in the mainstream literary community which mostly failed to recognize the importance of the growing alienation and despair in a society which offered many new things and possibilities, but personal happiness remaining elusive. The primary problem was the internal dissonance in an individual, where certain aspects of one's personality collided with the outward construction of morality and norms. The ever widening abyss of public and private life separated the parts of the psyche which should work in unison. Perhaps the greatest fault of these authors in the eyes of their contemporary society was that they showed that an individual's self-realization did not exclusively follow the dictates of a morally strict and conservative society. The raging battle between the façade and the inner self made the individual both inwardly and outwardly alienated and dysfunctional, and the absence of an equilibrium in such a complex thing as the human mind and soul made self-expression thwarted and frustrated, which is an increasingly pandemic psychological phenomenon in both urban and rural settings.

\section{Bibliography}

- Bush, Ronald (ed.) (1991) T. S. Eliot: The Modernist in History, Cambridge University Press, Cambridge, 1991.

- Eliot, T. S. (1963) Collected Poems, Harcourt, Brace \& World, New York, 1963.

- Hall, Donald (1959) „Interview with T. S. Eliot“, The Parisian Review, (November 27, 2013), <http://www.theparisreview.org/interviews/4738/the-art-of-poetry-no-1-t-s-eliot>, (23. VIII. 2019.).

- Modlin, Charles E., White, Lewis Ray, ed. (1996) Winesburg, Ohio, W. W. Norton \& Company, London, 1996.

- Scofield, Martin (1988) T. S. Eliot: The Poems, Cambridge University Press, Cambridge, 1988. 
Izvorni znanstveni članak

Primljen 2. IX. 2019.

Denis Kuzmanović

Filozofski fakultet Sveučilišta u Mostaru

\section{NEMOGUĆNOST SAMOIZRAŽAJA U ODABRANIM DJELIMA T. S. ELIOTA I SHERWOODA ANDERSONA}

\section{Sažetak}

Na prvi pogled T. S. Eliot i Sherwood Anderson nemaju mnogo toga zajedničkog glede njihovih djela. Eliot je prvenstveno poznat po poeziji, a Anderson po prozi. Prvi se smatra britanskim, a drugi američkim piscem. Eliot je jedno od najvećih imena književnoga modernizma, dok se Anderson smatra piscem realizma. Eliot je poznat po složenosti i enigmatičnosti svojih pjesama, dok se Andersonova djela usporedno čine mnogo jednostavnijima. Eliot je slavan zbog svojih urbanih prizora, a Anderson zbog svoje ruralne atmosfere. Međutim, postoji jedna poveznica između ovih dvaju autora: promišljanje o pojedničevoj nesposobnosti izražavanja u svome okruženju, gdje je ono pod utjecajem materijalizma, umjetničkih, seksualnih i drugih poriva, s pripadajućim represijama. Ovaj poriv za samoizražajem, ili samoostvarenjem, kosi se s običajima pojedničeva okruženja te njihovi neuspješni pokušaji izražavanja donose depresiju, frustraciju, represiju i otuđenje, nešto što su Eliot i Anderson dobro poznavali jer su se u svojim životima također nosili s problemima koji muče njihove protagoniste. Ono što je bitno kod analiziranja djela ovih pisaca jest ideja da je ova nesposobnost samoizražaja rasprostanjenija nego što se na prvi pogled čini, bez obzira na to živi li pojedinac u urbanome ili ruralnome okruženju. Razlike između ovih dvaju autora pri podrobnijoj analizi polako isparavaju te se pojavljuju i ostale sličnosti poput korištenja karikaturnih ili grotesknih likova kako bi se naglasila određena stanja uma (prva priča u Andersonovoj kolekciji Winesburg, Ohio zove se „Knjiga groteski“). Noćna atmosfera jako je važna kod obaju autora jer se tada pojedničeva introspekcija, uglavnom 
podsvjesna, pojačava. Društvena kritika također je jako bitna te oba autora promišljaju o skladu javnoga i privatnoga života unutar određene društvene zajednice.

Ključne riječi: T. S. Eliot; Sherwood Anderson; samoizražaj; modernizam; realizam; represija; društvo; groteska 